\title{
Cultural Values in a High School EFL Textbook in the Indonesian Context
}

\author{
Tuntun Sinaga*, Gede Eka Putrawan, Novita Nurdiana \\ Department of Language Education and Arts, Lampung University, Indonesia \\ Received February 20, 2020; Revised April 2, 2020; Accepted April 19, 2020
}

Copyright $(2020$ by authors, all rights reserved. Authors agree that this article remains permanently open access under the terms of the Creative Commons Attribution License 4.0 International License

\begin{abstract}
Although considerable amount of research on culture and ideology in textbooks has appeared previously in the literature, less attention has been paid to cultural values and gender ideology in EFL textbooks in the Indonesian context. They are inseparable from education goals that can form learners' characters in the context of national education system. Therefore, this study was aimed at explaining cultural values and identifying gender ideology contained in one of EFL textbooks in Indonesia. This study was conducted through a descriptive qualitative approach in which the data were collected from an EFL textbook through a systematic procedure of document analysis involving skimming, reading (thorough examination), and interpretation. The results indicate that the high school EFL textbook under investigation contains cultural values and gender ideology. Females are more prominent in terms of intellectual portrayals compared to males. However, females are still attached to a more sensitive and caring image about humanity. In terms of personality, both females and males have an intellectual personality trait, a thinker. However, being domestic work-oriented, parenting, and caring for family are traits and occupational roles attributed to females. In addition, females are represented as weak beings (victims), while males are positioned as a strong and brave character. Seen from ideological point of view, gender ideology is found in the form of women's wider emancipation in the public sphere, but the stereotype of women as weak and domestic work-oriented beings and the prominent role of men as "rulers" of life are still apparent. The implications for EFL textbook writing and recommendations for future research are also discussed.
\end{abstract}

Keywords Discourse Study, Cultural Values, EFL, Textbook, Indonesian Context

\section{Introduction}

Knowledge of national education has great importance for English as a foreign language (EFL) teaching and learning contexts. The national education in Indonesia refers to Law No. 20 of 2003 on National Education System (National Education System of the Republic of Indonesia, 2003) in which Article 1 states that education is a well-planned effort aiming at creating a learning environment for learners to develop their full potentials in terms of spiritual and religious strengths, self-control, personality, intelligence, morals, characters, and skills. Furthermore, in Article 3 it is also clearly stated that:

The national education functions to develop the capability, character, and civilization of the nation for enhancing its intellectual capacity, and is aimed at developing learners' potentials to become persons imbued with human values who are faithful and pious to one and only God; who possess morals and noble characters; who are healthy, knowledgeable, competent, creative, independent; and as citizens, are democratic and responsible.

By paying attention to the constitutional foundation stated above, a textbook as a learning medium, which can be defined as "a book that teaches a particular subject and that is used especially in schools and colleges" (Hornby, A. S., Wehmeier, S., \& Ashby, 2000, p. 1238), becomes an important part of education. Textbooks have been used as primary instruments by students since the $19^{\text {th }}$ century (Radic-Bojanic \& Topalov, 2016). They play a vital role in English teaching and learning in particular (Torres \& Hutchinson, 1994).

A textbook reflects not only the curriculum but also the mental awareness of the writer about the cultural values of the socio-cultural system. It reflects the learning objectives and cultural values of the supporting communities. In the process of book writing, the writer naturally makes a selection of contents or materials to be included in the book 
because it is a necessary aspect for any book writing (Barker, 2006). The inclusion of essential language and culture according to learners' needs, cultural background and linguistic proficiency is in need to be taken into account (Radic-Bojanic \& Topalov, 2016). Textbooks are said to be least analyzed when considering the ways at which education should be directed for improvement (Altbach, Kelly, Petrie, \& Weis, 1991). In this case high school English textbooks are assumed to contain ideology and cultural values transferred through information, knowledge in the form of texts and media (graphic illustrations) used in the classroom.

Seen from social reproduction theory, which is "important for a critical understanding of the relations between individual and society, how through the action of people, the social system is perpetuated" (Burton, 2014, p. 1802), it is argued that "schools are not institutions of equal opportunity but mechanisms for perpetuating social inequalities" (Collins, 2009, p. 33). Therefore, as part of education and learning system in the classroom, English textbooks are not sterile from the construction of social discourse in terms of information material, knowledge, language and media technology as well as graphic illustrations contained in the textbooks.

The issue of culture in EFL textbooks in Indonesia has received considerable attention. Integrating learners' culture in English teaching and learning can make learning more accomodating and meaningful and strengthen their national identity (Mahmud, 2019). When learning English as a compulsary subject in junior and high schools in Indonesia, the inclusion of culture also promotes their cultural awareness (Lekawael, Emzir, \& Rafli, 2018) that a critical approach represented through classroom materials helps learners develop and increase their intercultural awareness (Hollenback, 2017). A large body of data concerning cultural values in EFL textbooks in Indonesia has also been reported. Local values and culture exist in EFL textbooks (Cahyati \& Rahmijati, 2017; Parlindungan, Rifai, \& Safriani, 2018; Setyono \& Widodo, 2019). Therefore, it is generally accepted that culture and local values play an important role in EFL learning in Indonesia, although EFL textbooks which predominatly represent the target culture, the culture of English, in Indonesia also come into existence (Faris, 2014). Barton \& Sakwa (2012) state that gender bias exists in an English-language textbook in Uganda which is represented through the invisibility and silence of women, their employment in domestic roles and lower rank professions. Moreover, their emotion is also negatively represented. In other words, as found by Aljuaythin (2018), women are represented as marginalized and streotypical beings in which, according to Emilia, Moecharam, \& Syifa's (2017) finding, male characters are represented more frequently than female ones. Islam \& Niaz (2016) also found that only $37 \%$ of female characters are used in secondary school textbooks under their investigation, with passive and introvert characteristics and more traditional and lower rank occupations. They furthermore state that, based on their findings, in Indonesia the representation of female characters is balanced with a total of $45 \%$ of all character occurences. Sulaimani (2017) states that females in EFL textbooks in the Saudi Arabian context are underrepresented. Their characters are less frequently represented in the textbooks than the male ones. However, a fair representation of both females and males in an English language teaching textbook in Turkey also exists in which no gender inequality is found throughout the textbook (Demir \& Yavuz, 2017).

Although considerable amount of research on cultural values in textbooks has appeared previously in the literature, less attention has been paid to cultural values and gender ideology in the context of Indonesia. Therefore, this study was aimed at explaining cultural values and identifying gender ideology contained in one of EFL textbooks in Indonesia. Hence, an additional study of cultural values and gender ideology in an EFL textbook, which might be useful for teachers who are interested in the field of discourse studies and development of English textbooks in accordance with the objectives of English teaching and learning based on Indonesian cultural values and national education goals, was needed. This preliminary study was specifically aimed at addressing the following research question: What cultural values are represented in a high school EFL textbook in Indonesia?

\section{Literature Review}

Several studies reveal that ideology (gender) and cultural values contained in textbooks are transferred through various information presented by texts and multimedia in the forms of visual and graphic objects. Ideology in this case refers to "the tacit assumptions, beliefs and value systems which are shared collectively by social groups" (Hatim \& Mason, 1997, p. 144 as cited in Hatim \& Munday, 2004, p. 102). In other words, it is a basic orientation that contains assumptions, beliefs and value systems (Hatim \& Mason, 1997) to operate in social and cultural contexts, for example a selection of materials that is based on local, national or global orientations.

In the context of ideology, "schools, universities and the whole education system are among the most complex, elaborate and pervasive ideological institutions" (Dijk, 1998, p. 186). However, Tilaar (2007) states that education can be an instrument of power to preserve a certain ideology. For example, in the national education system in Indonesia phenomena of neoliberalism principles exist in which education opportunity is directed to people with certain economic classes, not in accordance with cultural values as mandated by the 1945 Constitution of the Republic of Indonesia (Sinaga, 2014). In addition, seen from the historical aspect, the mastery of English language 
and literature is included in post colonialism discourse. English learning and teaching throughout the world is also inseparable from the history and attempts of domination of English culture (Griffiths et al., 1989). Like ideology, knowledge and information contained in books tend not to be neutral and can reinforce the thinking about the dominant group or authority holders in society. In the context of education, Storey (as cited in Tilaar, 2004) states that:

pedagogy does not represent a neutral site, and is free from the operations of power and politics. Far from being the simple transmission of ready-made information, pedagogy is for Giroux a site of struggle, a terrain where the complex relations between knowledge and power are worked over.

In practice, English teaching and learning in Indonesia is directed at intercultural communication skills. Therefore, the selection of information and knowledge material should reflect Indonesian socio-cultural thinking, meaning that it should not be dominated by cultural elements of native speakers (British, American, and Australian). In addition, familiar contexts to learners' worldviews and culture should also be taken into account (Farzaneh, Kohandani, \& Nejadansari, 2014). As an international language, the local culture should be reflected in an EFL textbook rather than linked to the culture of the native speakers (Ahmad \& Shah, 2014).

The analysis of language in the current study refers to the function of language and symbols as a means of aesthetics and communication. In this analysis an understanding of the importance of language style, in addition to imagination, emotions, and intuition so that "messages" and meanings are absorbed by the reader, is needed. Aesthetics is presented through description (language) and visuals (images or photos). In this context, according to Danesi \& Perron (1999, p. 67), culture is "the system of shared meaning that is based on a signifying order." To understand this aesthetic meaning, the semiotic analysis proposed by Danesi (1994) about signs was used to understand cultural representations called as signifying orders which refer to "a complex system of different types of signs that coheres in predictable ways into patterns of representation which individuals and groups can utilize to make or exchange messages". Three key words in the formula include: (a) meaning, (b) understanding, and (c) communicative.

Semiotics is generally defined as "the study of signs or an epistemology about the existence or the actuality of sign in societal life" (Yakin \& Totu, 2014, p. 4). Umberto Eco (1979 as cited in Yakin \& Totu, 2014) states that semiotics refers to everything that can be considered as a sign, which significantly substitutes something for something else.

Semiotic theory is used to dismantle gender ideology and cultural values contained in the EFL textbook under investigation into linguistic and non-linguistic features. This theory was initially introduced by two prominent figures, namely Ferdinand de Saussure (1857-1913) and Charles Sander Pierce (1839-1914), the former had a background in linguistics, while the latter in philosophy. Both of them have developed semiotics and made great contributions to the field from different perspectives. Today, the semiotic approach has been used as references in various disciplines of thought, not only in the field of linguistics and philosophy but also in arts and humanities e.g. antropology, psychology, text analysis, mathematics, communication, and so on (Yakin \& Totu, 2014).

The main focus of Saussure's theory about semiotics is the principle that emphasizes "language as a system of signs." The system of linguistic signs is "the most superior sign system compared to other sign systems in the real world" since it plays a vital role in constructing reality (Yakin \& Totu, 2014, pp. 5-6). According to Saussure, a sign is a unit of two inseparable fields, like a piece of paper. A sign (word or picture) has two aspects that are captured by the human senses called signifier, a marker field or another aspect form called signified, a signified field or concept or meaning. The second aspect is contained in the first.

The primary principles of Peirce's theory are closely related to "the human mind and sign boundaries, the three-dimensional system (triadic/trichotomy) and the relativity regarding the three typologies or taxonomies of signs (icon, index and symbol)" (Yakin \& Totu, 2014, p. 6). An icon is a sign between the sign and the reference which has a similarity relationship and is usually called a metaphor. An example of an icon is portrait. Index refers to a close relationship of existence, for example, a sign of arrow pointing which shows a certain place around it. A symbol refers to signs in which their existence is recognized based on convention, for example written language.

To Barthes (1985), an important factor in the connotation is the marker in the first order. If this theory is associated with various texts contained in the textbook being discussed, then each text message refers to the signifier (layer of expression) and signified (layer of meaning). Through verbal and visual elements, two levels of meaning are obtained, namely the denotative meaning found in the first level of semiosis and the connotative one obtained from the next level of semiosis. In this study, Pierce's theory was used to analyze and interpret the visual materials, to look at the signs contained in the textbook (icons, indexes, symbols), while the Saussure's theory was used to see the signifier and signified. The Barthes's theory was directed to look at how codes operate in revealing ideology through various codes: hermeneutic codes, semantic codes, symbolic codes, narrative codes and cultural codes.

\section{Materials and Methods}

This study was conducted through a descriptive qualitative approach in which the data were taken from an 
EFL textbook entitled Developing English Competencies for Senior High School (SMA/MA) (Doddy, Sugeng, \& Effendi, 2008). The selected book was a high school English textbook which was aimed at helping students improve their English competence and competitiveness after graduation in the context of Indonesian national education system in the era of globalization. This study was conducted for four months in Bandar Lampung, Sumatra island, Indonesia.

The data were collected through a systematic procedure of document analysis which "involves skimming (superficial examination), reading (thorough examination), and interpretation" (Bowen, 2009, p. 32). The document analyses consist of both content and thematic analyses, the former refers to how information is categorically organized in accordance with the central aims of the research (Bowen, 2009), while the latter refers to the recognition of patterns within the data (Fereday \& Muir-Cochrane, 2006 as cited in Bowen, 2009). In addition, the analysis was also undertaken through semiotic approach and critical discourse study which focused on the elements of the textbook, texts, linguistic and non-linguistic features, which contained "hidden" ideology, representing the formal education system in a society and which can be said to be ideological (Barker, 2006).

\section{Results and Discussion}

The Developing English Competencies for Senior High School (SMA/MA) (Doddy et al., 2008) textbook was designed to help the eleventh grade students of senior high school in Indonesia communicate in English in accordance with the context of language use. This literacy-based approach helped them get more English learning experiences and exposures to the aspects of interpretation, convention, collaboration, cultural knowledge, problem solving, reflection, and language use.

The textbook under study consists of 10 chapters and 2 reviews. Each chapter includes four language skills, listening, speaking, reading and writing with linguistic features, contents, and media. It comprises some different types of texts.

\subsection{Gender Ideology, Quality, and Cultural Imagery}

Gender and cultural values in the textbook under investigation are found through linguistic features, which are quoted from various texts that describe gender ideology (role division), quality and cultural imagery as presented in Table 1 below.

Table 1. Gender ideology, quality, and cultural imagery

\begin{tabular}{|c|c|}
\hline Female & Male \\
\hline $\begin{array}{l}\text { - She must give a general lecture at the university at } 11 \text { a.m. (p. 7) } \\
\text { - She is a qualified teacher here (p. 29) } \\
\text { She is a member of an outstanding writing society in Indonesia } \\
\text { and is the award-winning author of some best-selling books (p. } \\
\text { 70) } \\
\text { - She has written several books in the same field (p. 73) } \\
\text { - She is giving advice to Danu (p. 28) } \\
\text { - She advised me to study hard (p. 31) } \\
\text { She advises me to do the best (p. 32) } \\
\text { What she does is for the goodness of her children (p. 32) } \\
\text {-.. because she didn't want me to fail (p. 32) } \\
\text {-.. she gave them all a great big hug (p. 38) } \\
\text { When she came to the river, she saw a peach floating down the } \\
\text { stream; so she picked it up, and carried it home with her, thinking } \\
\text { to give it to her husband to eat when he should come in (p. 42) } \\
\text { But she has to take her mother to see a doctor after work (p. 116) } \\
\text { She was unhappy all the time, for she felt that she was intended } \\
\text { for a life of refinement and luxury (p. 209) } \\
\text { Tia is feeling sad because somebody she trusts is a traitor (p. 110) } \\
\text { A girl should not only beautify her face but also her thought, heart, } \\
\text { and the way she behaves (p. 246) } \\
\text { Sinta doesn't go to school because she is sick (p. 47) } \\
\text { "There's nothing I can do about this problem now," she sighed (p. } \\
\text { 113) }\end{array}$ & $\begin{array}{l}\text { - He cannot be disturbed. He is very busy (p. 31) } \\
\text { He has a number of research and surveys in the related field } \\
\text { (p. 82) } \\
\text { Well, Ladies and Gentlemen, give a big applause to Ian } \\
\text { Blackley. That in his age he gives so much attention to the } \\
\text { problems around us. He can be a good example for the young } \\
\text { generation (p. 93) } \\
\text { As the years went by, he remained small, but he became a } \\
\text { kind and intelligent boy. One day, it was necessary to take } \\
\text { the cart and go and fetch his father (p. 236) } \\
\text { Yeah. I am with you. But don't be angry with him. Just ask } \\
\text { him why he didn't go to school for } 3 \text { days and where he went } \\
\text { (p. 9) } \\
\text { A man is stopped by a policewoman because he violated a } \\
\text { traffic regulation (p. } 30 \text { ) } \\
\text { I must stop my studies because my father retired three } \\
\text { months ago. So he cannot pay my school fees (p. } 7 \text { ) } \\
\text { Why did he want to finish everything quickly? (p. 26) } \\
\text { He is in the admonition of God (p. } 31 \text { ) } \\
\text { Ali was a lazy man. He looked for leaves for about ten } \\
\text { minutes and then he climbed a tree to sleep. He was afraid of } \\
\text { wolves. When he woke up, he was surprised to see forty } \\
\text { thieves on forty horses. They stopped in front of a big rock } \\
\text { (p. } 33 \text { ) } \\
\text {... he loaned his horns without hesitation, just twisting them } \\
\text { right off his head (p. } 35 \text { ). }\end{array}$ \\
\hline
\end{tabular}


In terms of public roles and intellectual values, gender equality values are found through employment or professions (e.g. lecturers, book authors). This finding is not in line with Barton \& Sakwa's (2012) finding in which they state females have lower rank professions. This suggests that females are encouraged to take non-traditional careers (Demir \& Yavuz, 2017) which sounds positive without any discriminatory practices (Demir \& Yavuz, 2017) as shown in the following excerpts.

"She must give a general lecture at the university at 11 a.m." (p. 7)

"She is a qualified teacher here." (p. 29)

"She is a member of an outstanding writing society in Indonesia and is the award-winning author of some best-selling books." (p. 70)"

"She has written several books in the same field." (p. 73)

In general, females in this book are more prominent in terms of intellectual portrayals compared to males (e.g.
"Ali was a lazy man"). On the other hand, women are still attached to a more sensitive and caring image about humanity or feelings towards people, which is in line with Emilia, Moecharam, \& Syifa's (2017) findings, as shown in the following excerpts.

"She is giving advice to Danu." (p. 28)

"She advised me to study hard." (p. 31)

"She advises me to do the best." (p. 32)

"What she does is for the goodness of her children." (p. 32)

“... because she didn't want me to fail." (p. 32)

“... she gave them all a great big hug." (p. 38)

"When she came to the river, she saw a peach floating down the stream; so she picked it up, and carried it home with her, thinking to give it to her husband to eat when he should come in." (p. 42)

In the following Table 2, the roles and traits of gender are also found as follows.

Table 2. Gender: Roles and traits of males and females

\begin{tabular}{|c|c|c|}
\hline Male & $\begin{array}{l}\text { Roles and } \\
\text { Traits }\end{array}$ & Female \\
\hline \multirow[t]{3}{*}{$\begin{array}{l}\text { He cannot be disturbed. He is very busy (p. 31) } \\
\text { He has a number of research and surveys in the related } \\
\text { field (p. 82) } \\
\text {... give a big applause to Ian Blackley. That in his age he } \\
\text { gives so much attention to the problems around us. He } \\
\text { can be a good example for the young generation (p. } 89 \text { ) } \\
\text { As the years went by, ... but he became a kind and } \\
\text { intelligent boy. One day, it was necessary to take the cart } \\
\text { and go and fetch his father, (p. 236) }\end{array}$} & $\begin{array}{l}\text { Intellectual/ } \\
\text { thinker }\end{array}$ & $\begin{array}{l}\text { She must give a general lecture at the university at } 11 \text { a.m. } \\
\text { (p. 7) } \\
\text { She is a qualified teacher here (p. 29) } \\
\text { She is a member of an outstanding writing society in } \\
\text { Indonesia and is the award-winning author of some best } \\
\text { selling books (p. 70) } \\
\text { She has written several books in the same field (p. 73) }\end{array}$ \\
\hline & $\begin{array}{l}\text { Domestic work, } \\
\text { parenting, and } \\
\text { caring for the } \\
\text { family }\end{array}$ & $\begin{array}{l}\text { She is giving advice to Danu (p. 28) } \\
\text { She advised me to study hard (p. 31) } \\
\text { She advises me to do the best.( } 32 \text { ) } \\
\text { What she does is for the goodness of her children (p. 32) } \\
\text {... because she didn't want me to fail (p. 32) } \\
\text {... she gave them all a great big hug (p. 38) } \\
\ldots \text { she saw a peach floating down the stream; so she picked } \\
\text { it up, and carried it home with her, thinking to give it to her } \\
\text { husband to eat when he should come in (p. 42) } \\
\text { But she has to take her mother to see a doctor after work (p. } \\
116 \text { ) } \\
\text { She was unhappy all the time, for she felt that she was } \\
\text { intended for a life of refinement and luxury (p. 209) }\end{array}$ \\
\hline & Victim & $\begin{array}{l}\text { Tia is feeling sad because somebody she trusts is a traitor } \\
\text { (p. 110) }\end{array}$ \\
\hline $\begin{array}{l}\text { Yeah. I am with you. But don't be angry with him. Just } \\
\text { ask him why he didn't go to school for } 3 \text { days and where } \\
\text { he went (p. 9) } \\
\text { A man is stopped by a policewoman because he violated } \\
\text { a traffic regulation (p. 30) }\end{array}$ & $\begin{array}{l}\text { Weak, women } \\
\text { as "weak" } \\
\text { creatures }\end{array}$ & $\begin{array}{l}\text { A girl should not only beautify her face but also her } \\
\text { thought, heart, and the way she behaves (p. 246) } \\
\text { Sinta doesn't go to school because she is sick. "There's } \\
\text { nothing I can do about this problem now," she sighed. All } \\
\text { she could do was weep to herself in secret (p. 47) }\end{array}$ \\
\hline $\begin{array}{l}\text {... I must stop my studies because my father retired three } \\
\text { months ago. So he cannot pay my school fees (p. 7) } \\
\text { Why did he want to finish everything quickly? (p. 26) } \\
\text { He is in the admonition of God (p. 31) } \\
\text { Ali was a lazy man. When he woke up, he was surprised } \\
\text { to see forty thieves on forty horses. They stopped in front } \\
\text { of a big rock. (p. 44) - fiksi- the millipede offered, he } \\
\text { loaned his horns without hesitation, just twisting them } \\
\text { right off his head (p. 33) }\end{array}$ & $\begin{array}{l}\text { Strong and } \\
\text { brave }\end{array}$ & \\
\hline
\end{tabular}


Table 2 illustrates that both females and males have an intellectual personality trait, both are thinkers. This finding is in line with Islam \& Niaz's (2016) finding that states that in the context of Indonesia the representation of characters between males and females is balanced and Demir \& Yavuz's (2017) finding that states that no gender inequality exists. Being domestic work-oriented, parenting, and caring for the family are traits and occupational roles attributed to females. This finding is in line with Barton \& Sakwa's (2012) finding that states women are also restricted to domestic sphere in which they are frequently portrayed in a housewife-mother capacity, they do household tasks and care for their family.

Females are portrayed as victims, which is in line with Wright's (1995) finding (as cited in Islam \& Niaz, 2016). They are represented as weak beings, which is in line with
Barton \& Sakwa's 2012) finding that states women are negatively presented and positioned as a weak character. On the contrary, males are positioned as a strong and brave character, which is in line with the findings of Barton \& Sakwa, 2012; Sulaimani, 2017; Hussain, Naz, Khan, Daraz, \& Khan, 2015 as cited in Aljuaythin, 2018; Chung, 2000 as cited in Amerian \& Esmaili, 2015.

\subsection{Visual Analysis}

The representation through language, which is supported by using pictures/photos/live images, in this book refers to the realm of education, specifically classrooms and English learning activities. The analysis of both first level signifier and second level signified is shown in Table 3 as follows.

Table 3. First level signifier and second level signified

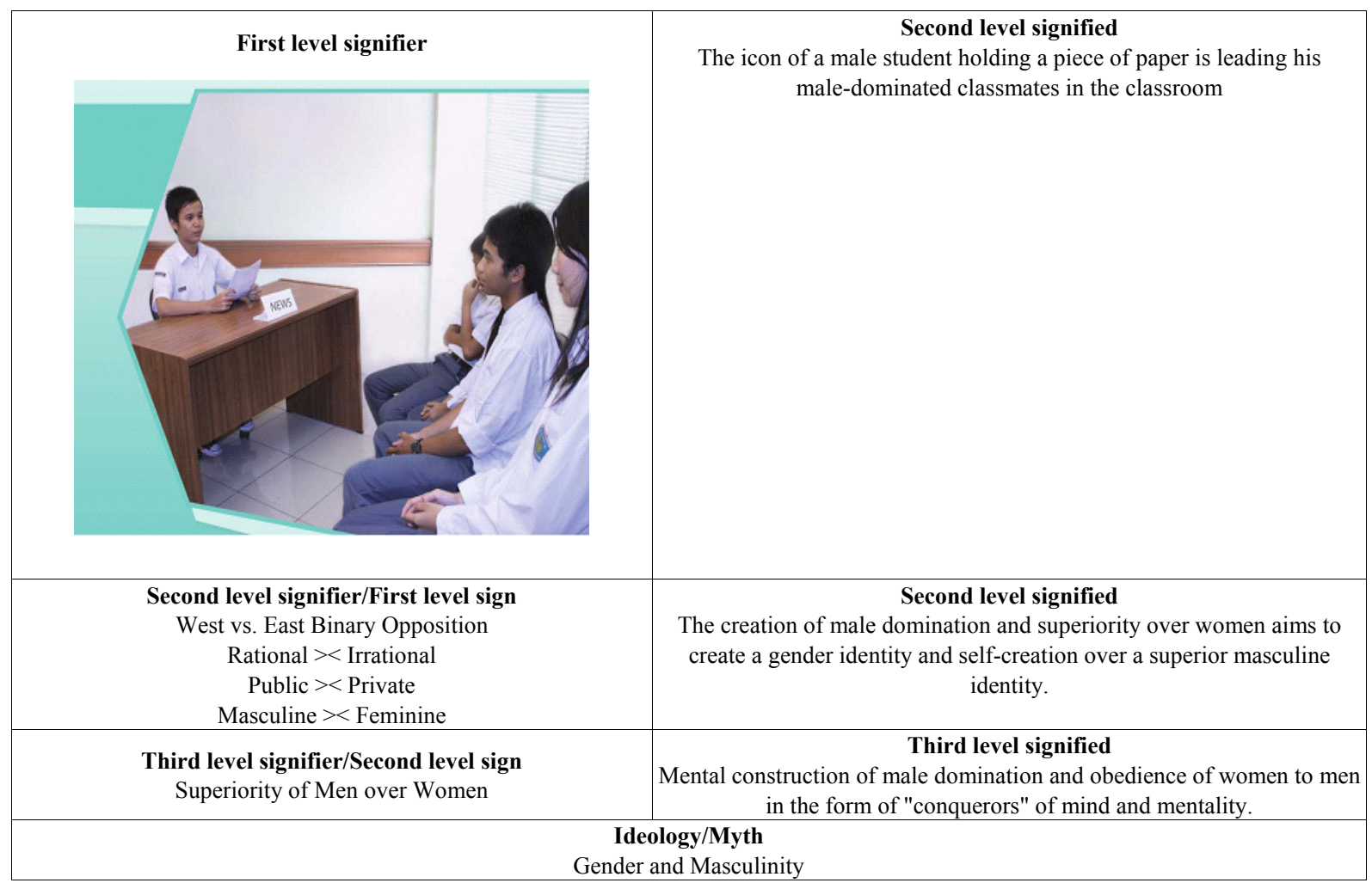


Table 3 gives information that, semiotically, the photo in the book cover is a welcome for students. The first level signifier of this photo depicts the class situation as a "whole" with icons which then function as signified. They include an icon of a male student holding a piece of paper (educated) is leading his male-dominated classmates in the classroom. At this stage the signifier and signified are still denotative. At the connotative level, the first level signifier which then becomes the second level signifier indicates the existence of binary opposition between Men and Women, Masculine vs. Feminine. This signifier in semiosis (Barthesian) is referred to as signified, the creation of an "image" of male domination of women in the context of masculinity identity formation when dealing with women. At the third level, the element of signifiers and signified contained in the second level signs becomes a myth. As a myth, this visual image constructs a mental image of gender in an ideological context. Overall, the values of "aesthetics" or visual texts that emerge are the dominance and discrimination of social classes and gender stereotypes, imaging that men's identities are more "superior" than women. This findings are consistent with findings of Emilia et al. (2017) who states that characters are dominated by men.

The findings of the present study indicate that the EFL textbook under investigation contains cultural value systems which are inseparable from ideology such as gender. Seen from the ideological point of view, gender ideology is found in the forms of values of women's emancipation in the public sphere, but the stereotype of women as weak and domestic work-oriented beings and the prominent role of men as "rulers" of life are still apparent, which is consistent with findings of Khalid \& Ghania (2019). Women are still attributed to domestic roles (Barton \& Sakwa, 2012), which refers to gender imbalance reflecting women as marginalized stereotypical beings (Aljuaythin, 2018).

\section{Conclusions}

The findings in this study shed light on the content of Indonesian EFL textbook in terms cultural values and gender ideology. Females in the EFL textbook are more prominent in terms of intellectual portrayals compared to males. However, females are still attached to a more sensitive and caring image about humanity. In terms of personality, both females and males have an intellectual personality trait, a thinker. However, being domestic work-oriented, parenting, and caring for family are traits and occupational roles attributed to females. In addition, females are represented as weak beings, as victims, while males are positioned as a strong and brave character. Gender ideology is found in the form of women's wider emancipation in the public sphere, but the stereotype of women as weak and domestic work-oriented beings and the prominent role of men as "rulers" of life are still apparent.

These findings have several significant implications for EFL textbook writing in the context of Indonesia. Teachers, educators, and related-policy makers need to consider cultural and ideological aspects in the preparation, production and use of EFL textbooks in the context of culture-based curriculum (local and national) and global vision. Weninger \& Kiss (2013, p. 19) state that linguistic competence is insufficient if a foreign language learning is aimed at fostering "intercultural citizenship and critical understanding of self and other in a global world." Learners need more chances to comprehend their own culture (Chao, 2011) and integrating their cultural values into EFL textbooks can strengthen their national identity (Mahmud, 2019). Developing guidelines for the production of gender-fair materials is also of great importance to promote gender equality (Lee, 2019) because education is the best way to promote this issue and a careful language use should also be taken into account. Inappropriate language use may unintentionally reinforce stereotypes and gender inequality so that a textbook should be free from gender bias (Aydınoğlu, 2014).

However, this study is not without limitations. It will be useful to extend this research to studies with a variety of EFL textbooks available in the market accross different geographical areas around the globe with more diverse cultural backgrounds to find out if the findings are globally similiar to each other.

\section{Acknowledgments}

We are very grateful to reviewers for their appropriate and constructive suggestions to improve this paper.

\section{REFERENCES}

[1] Ahmad, H., \& Shah, R. (2014). EFL textbooks: Exploring the suitabilty of textbook contents from EFL teachers` perspective. VFAST Transactions on Education and Social Sciences, 5(1), 10-18.

[2] Aljuaythin, W. (2018). Gender representation in EFL textbooks in Saudi Arabia: A critical discourse analysis approach. International Journal of Applied Linguistics and English Literature, 7(5), 151. https://doi.org/10.7575/aiac.i jalel.v.7n.5p. 151

[3] Altbach, P. G., Kelly, G. P., Petrie, H. G., \& Weis, L. (Eds.). (1991). Textbook in American society: Politics, policy, and pedagogy. New York: SUNY Press.

[4] Amerian, M., \& Esmaili, F. (2015). A brief overview of critical discourse analysis in relation to gender studies in English language textbooks. Journal of Language Teaching and Research, 6(5), 1033-1043. https://doi.org/10.17507/j1 tr.0605.16 
[5] Aydınoğlu, N. (2014). Gender in English language teaching coursebooks. Procedia - Social and Behavioral Sciences, 158, 233-239. https://doi.org/10.1016/j.sbspro.2014.12.081

[6] Barker, C. (2006). Cultural studies: Teori dan praktik (H. Purwanto, Ed.; Nurhadi, Trans.). Retrieved from http://opac.perpusnas.go.id/DetailOpac.aspx?id=50040

[7] Barthes, R. (1985). L'aventure semiologique. Paris: Editions du Seuil.

[8] Barton, A., \& Sakwa, L. N. (2012). The representation of gender in English textbooks in Uganda. Pedagogy, Culture and Society, 20(2), 173-190. https://doi.org/10.1080/14681 366.2012.669394

[9] Bowen, G. A. (2009). Document analysis as a qualitative research method. Qualitative Research Journal, 9(2), 2740. https://doi.org/10.3316/qrj0902027

[10] Burton, M. (2014). Encyclopedia of critical psychology. In T. Teo (Ed.), Encyclopedia of Critical Psychology. https://doi.org/10.1007/978-1-4614-5583-7

[11] Cahyati, S. S., \& Rahmijati, C. (2017). Exploring local values and culture in English textbook. Lingual: Journal of Language and Culture, 4(2), 1-6. https://doi.org/10.24843/ lj1c.2017.v04.i02.p07

[12] Chao, T. (2011). The hidden curriculum of cultural content in internationally published ELT textbooks: A closer look at new American inside out. Journal of Asia TEFL, 8(2), 189210 .

[13] Collins, J. (2009). Social reproduction in classrooms and schools. Annual Review of Anthropology, 38(1), 33-48. https://doi.org/10.1146/annurev.anthro.37.081407.085242

[14] Danesi, M. (1994). Cool: the signs and meanings of adolescence (pp. xiv, 168 p.). pp. xiv, 168 p. Retrieved from file://catalog.hathitrust.org/Record/002952546

[15] Danesi, M., \& Perron, P. (1999). Analyzing cultures: An introduction and handbook. Bloomington and Indianapolis: Indiana University Press.

[16] Demir, Y., \& Yavuz, M. (2017). Do ELT coursebooks still suffer from gender inequalities? A case study from Turkey. Journal of Language and Linguistic Studies, 13(1), 103122.

[17] Dijk, T. A. van. (1998). Ideology: A multidisciplinary approach. https://doi.org/10.4135/9781446217856

[18] Doddy, A., Sugeng, A., \& Effendi, E. (2008). Developing English competencies for senior high school (SMA/MA). Jakarta: Pusat Perbukuan Departemen Pendidikan Nasional.

[19] Emilia, E., Moecharam, N. Y., \& Syifa, I. L. (2017). Gender in EFL classroom: Transitivity analysis in English textbook for Indonesian students. Indonesian Journal of Applied Linguistics, 7(1), 206-214. https://doi.org/10.17509/ijal.v7 i1.6877

[20] Faris, I. N. I. (2014). Cultural content analysis of an English textbook for senior high school grade three in Cianjur, West Java. Journal of English and Education, 2(2), 14-25. Retrieved from http://ejournal.upi.edu/index.php/L-E/articl e/view/4599

[21] Farzaneh, N., Kohandani, M., \& Nejadansari, D. (2014). A textbook evaluation of socio-cultural contexts in Top Notch Series. International Conference on Current Trends in ELT - Procedia - Social and Behavioral Sciences, 98, 472-481. https://doi.org/10.1016/j.sbspro.2014.03.442

[22] Griffiths, G., Menin, S., Ashcroft, B., Ashcroft, F. M., Griffiths, G., \& Tiffin, H. (1989). The Empire writes back: Theory and practice in post-colonial literatures (2nd ed.). Routledge.

[23] Hatim, B., \& Mason, I. (1997). The translator as communicator. In The Translator as Communicator. https://doi.org/10.4324/9780203992722

[24] Hatim, B., \& Munday, J. (2004). Translation: An advanced resource book.https://doi.org/10.1017/CBO978110741532 4.004

[25] Hollenback, M. D. (2017). A critical look at culture in EFL textbooks in Japan. In A. Clements, Krause, \& H. Brown (Eds.), Transformation in Language Education. Tokyo: JALT.

[26] Hornby, A. S., Wehmeier, S., \& Ashby, M. (Ed.). (2000). Oxford advanced learner's dictionary (OALD) (6th ed.). Oxford: Oxford University Press.

[27] Islam, K. M. M., \& Niaz, A. M. (2016). Gender stereotypes and education: A multi-country content analysis study of secondary school textbooks. UCLA Thinking Gender Papers.

[28] Khalid, Z., \& Ghania, O. (2019). Gender positioning in the visual discourse of Algerian secondary education EFL textbooks: Critical image analysis vs teachers' perceptions. Journal of Language and Linguistic Studies, 15(3), 773793. https://doi.org/10.17263/j1ls.631510

[29] Lee, J. F. K. (2019). In the pursuit of a gender-equal society: Do Japanese EFL textbooks play a role? Journal of Gender Studies, 28(2), 204-217.https://doi.org/10.1080/09589236. 2018.1423956

[30] Lekawael, R. F. J., Emzir, E., \& Rafli, Z. (2018). The cultural values in texts of English coursebooks for junior high school in Ambon, Moluccas, Indonesia. Advances in Language and Literary Studies, 9(2), 24-30. https://doi.org/10.7575/aiac.alls.v.9n.2p.24

[31] Mahmud, Y. S. (2019). The representation of local culture in Indonesian EFL textbooks: Rationales and implications. Indonesian EFL Journal, 5(2), 61-72. https://doi.org/10.25 134/ieflj.v5i2.1727

[32] National Education System of the Republic of Indonesia. Pub. L. No. 20 (2003)

[33] Parlindungan, F., Rifai, I., \& Safriani, A. (2018). The representation of Indonesian cultural diversity in middle school English textbooks. Indonesian Journal of Applied Linguistics, 8(2), 289-302. https://doi.org/10.17509/ijal.v8 i2.13276

[34] Radic-Bojanic, B., \& Topalov, J. (2016). Textbooks in the EFL classroom: Defining, assessing and analyzing. Review Paper, XLVI(3), 137-153. https://doi.org/10.5937/zrffp46-12094

[35] Setyono, B., \& Widodo, H. P. (2019). The representation of multicultural values in the Indonesian Ministry of Education and Culture-Endorsed EFL textbook: a critical 
discourse

analysis. Intercultural Education, 30(4), 383-397. https://d oi.org/10.1080/14675986.2019.1548102

[36] Sinaga, T. (2014). Hegemony of international standard education at public senior high school 78, Jakarta. Journal of Cultural Studies, 7(2).

[37] Sulaimani, A. (2017). Gender representation in EFL textbooks in Saudi Arabia: A fair deal? English Language Teaching, 10(6), 44-52. https://doi.org/10.5539/elt.v10n6p 44

[38] Tilaar, H. A. (2004). Paradigma baru pendidikan nasional. Jakarta: PT. Rineka Cipta.

[39] Torres, E., \& Hutchinson, T. (1994). The textbook as agent of change. ELT Journal, 48(October), 315-328.

[40] Weninger, C., \& Kiss, T. (2013). Culture in English as a foreign language (EFL) textbooks: A semiotic approach. TESOL Quarterly, 47(4), 694-716.https://doi.org/10.1002/ tesq. 87

[41] Yakin, H. S. M., \& Totu, A. (2014). The semiotic perspectives of Peirce and Saussure: A brief comparative study. Procedia - Social and Behavioral Sciences, 155(October), 4-8. https://doi.org/10.1016/j.sbspro.2014.1 0.247 